\title{
Faktor Risiko yang Berhubungan dengan Infeksi HIV pada Pengguna Napza Suntik (Penasun) DKI Jakarta Tahun 2013-2014
}

\author{
Risk Factor Which Related to HIV Infection in Injected Drug Users \\ IDUs at DKI Jakarta in 2013-2014.
}

\author{
Inggariwatiak; Sudarto Ronoatmodjob
}

a Dinas Kesehatan Prov. DKI Jakarta, Jl. Kesehatan no 10 Jakarta Pusat Indonesia

b Departemen Epidemiologi Fakultas Kesehatan Masyarakat Universitas Indonesia, Lantai 1 Gedung A Kampus Baru UI Depok 16424, Indonesia

\section{ABSTRAK}

Prevalensi HIV pada kelompok Penasun selalu menduduki peringkat tertinggi dibanding kelompok populasi kunci lainnya. Studi cross sectional dilakukan untuk mengetahui faktor risiko yang berhubungan dengan infeksi HIV pada populasi Penasun DKI Jakarta. Penelitian ini menggunakan data sekunder dari pelaksanaan Sero Survei HIV/Sifilis yang terintegrasi dengan Survei Cepat Perilaku di DKI Jakarta pada tahun 2013 - 2014. Populasi penelitian ini adalah Penasun di DKI Jakarta, sampel 240, pemilihan sampel menggunakan metode RDS (Responden Driven Sampling). Model akhir analisis multivariate cox regression menunjukkan bahwa variabel yang paling berkontribusi terhadap infeksi HIV di kalangan Penasun adalah sikap sharing jarum suntik PR 2,42 (95\% CI = 1,33 4,41) dan lama menjadi Penasun PR 1,78 (95\% CI = 1,23-2,57). Sikap sharing jarum suntik walaupun hanya dilakukan sekali berdampak kuat meningkatkan risiko infeksi HIV dan variabel lama menjadi penasun berpengaruh terhadap melemahnya sikap konsisten untuk tidak sharing jarum suntik.

Kata kunci : Penasun, RDS, cox regression, sharing jarum suntik, lama jadi penasun

\author{
A B STRACT
}

HIV prevalence in IDU groups always ranks highest compared to other key population groups. We conducted a cross sectional study to analyze associated factors among 240 samples of IDUs (Injecting Drug Users) from the Sero HIV/Syphilis Survey integrated with Rapid Behavior Survey in DKI Jakarta year 2013-2014, sample selection was using the RDS (Respondent Driven Sampling) method. Cox regression analysis were used to calculate Prevalence Ratio between associated factors with HIV infection among IDUs. Multivariate Cox Regression analysis showed that sharing needles behavior among IDUs were at higher risk ( $P R=2,42 ; 95 \% \mathrm{Cl}$ $=1,33-4,41, P$ value $=0,004$ ) compared with those that was not sharing needles. Patients with length time of being an IDU 120-240 moths also have higher risk to get HIV than those with length time $<120$ months $(P R=1,78 ; 95 \%$ CI : 1,23-2,57, $P$ value $=0,015)$. Syringe sharing, although only once having a strong impact on increasing the risk of HIV infection, is due to the high prevalence of HIV among IDUs, a long time being IDU has an effect on the weakening of not sharing syringe behaviour.

Keywords : IDU, RDS, cox regression, sharing syringe, duration of use syringe

\section{Laki-laki Seks dengan Laki-laki (LSL) dan Waria. ${ }^{2}$}

Dari tahun ke tahun prevalensi HIV pada kelompok Penasun selalu menduduki peringkat tertinggi dibanding pada kelompok populasi kunci lainnya. Tren prevalensi HIV pada kelompok Penasun hampir sama dengan Waria cenderung tetap sedangkan pada kelompok Laki-laki Suka Seks Laki-laki (LSL) trennya meningkat, sebaliknya pada kelompok Wanita Pekerja Seks Tidak Langsung (WPSTL) trennya turun. Berdasarkan data dari Surveilans HIV DKI Jakarta hasil dari Survei Terpadu Biologis Perilaku (STBP) tahun 2007, 2011, 2013 dan 2015 didapatkan prevalensi HIV di kalangan Penasun berturut-turut adalah 55\%, 39\%, 49.2\% dan 2015 sebesar 43,6\%. ${ }^{3}$ Sangat tinggi dibanding prevalensi HIV global Penasun berdasarkan hasil studi sistematik reviu yang dilakukan oleh Degenhardt tahun 2017 yakni 17.8\%; 95\% CI = 10.824.8\%. ${ }^{4}$ Sementara dalam literatur lain menyebutkan prevalensi HIV dikalangan Penasun di 3 Negara dengan populasi Penasun terbesar yakni China, Amerika Serikat *Korespondensi: Inggariwati. Dinas Kesehatan Prov. DKI Jakarta, Jl. Kesehatan no 10 Jakarta PusatIndonesia.E-mail:inggariwati@gmail.com 
Jurnal Epidemiologi Kesehatan Indonesia Vol. 2, No. 2, Desember 2018 dan Rusia masing-masing sebesar 12\%, 16\% dan 37\%. ${ }^{5}$ Jumlah penyalahgunaan Napza meningkat sangat cepat, terutama mereka yang menggunakan jarum suntik tidak steril. Di Jakarta, 68\% dari pasien yang berobat di RSKO adalah pengguna jarum suntik, sebanyak 72,7\% dari jumlah tersebut sering menggunakan jarum suntik yang tidak steril ketika mereka menyuntikkan heroin. Sebanyak 59\% dari mereka saling bertukar alat suntik.²

Berdasarkan ulasan Kementerian Kesehatan meskipun pada awalnya HIV disebabkan oleh penggunaan jarum suntik bersama di kalangan Penasun namun penularan melalui hubungan seksual saat ini merupakan cara penularan HIV paling utama. Jumlah infeksi baru per tahun diperkirakan mencapai sekitar 49.000. Pada studi ini dianalisis sejumlah variabel yang berhubungan dengan infeksi HIV di kalangan Penasun diantaranya perilaku pemakaian jarum suntik secara bergantian, faktor demografi dan untuk mengetahui apakah perilaku seks juga berperan pada infeksi HIV di kalangan Penasun dianalisis pula faktor risiko seksualnya. Tujuan dari studi ini adalah untuk mengetahui faktor risiko yang berhubungan dengan infeksi HIV pada populasi Penasun DKI Jakarta.

\section{Metode Penelitian}

Penelitian ini berjenis observasional analitik disain cross sectional menggunakan data sekunder dari pelaksanaan Sero Survei HIV/Sifilis yang terintegrasi dengan Survei Cepat Perilaku di DKI Jakarta pada tahun 2013 - 2014. Kegiatan Survei ini dibawah tanggung jawab Kemenkes RI Dirjen P2PL sebagai agenda rutin yang dilaksanakan 2 tahun sekali dalam rangka pengamatan epidemi HIV, kegiatan dilakukan di 11 Provinsi 13 Kab/Kota, pelaksana adalah Dinas Kesehatan Provinsi bekerjasama dengan Komisi Penanggulangan AIDS Provinsi (KPAP), kegiatan ini telah melalui prosedur kaji etik dan layak dilaksanakan sesuai dengan Surat Keterangan dari Komisi Ahli Riset dan Etik Riset FKM UI no. 129/H2.F10/PPM.00.02/2014. Populasi pada penelitian ini adalah kelompok Penasun di DKI Jakarta. Definisi operasional Penasun adalah pria/wanita berumur e" 15 tahun tinggal di Jakarta minimal selama sebulan, menyuntikkan Napza dalam satu tahun terakhir dan belum ikut serta sebagai responden dalam survei ini. ${ }^{6}$

Jumlah sampel sebanyak 240 responden berdasarkan perhitungan jumlah sampel minimal pada kegiatan sero survei HIV/Sifilis yang bertujuan untuk menghitung prevalensi HIV di kalangan Penasun. Status infeksi HIV dan Sifilis diukur dengan pemeriksaan laboratorium, pemeriksaan HIV menggunakan strategi 2 yakni menggunakan 2 jenis reagen yang telah memenuhi kriteria sensitifitas dan spesifisitas (sensitifitaas reagen per

tama $>99 \%$ dan spesifisitas reagen kedua $>98 \%$ ) sesuai dengan tujuan studi yakni untuk screening, sedangkan pemeriksaan sifilis menggunakan 3 stage yakni RPR, TP Rapid serta RPR titer karena tujuannya disamping untuk screening sekaligus untuk pengobatan. ${ }^{\text {? }}$

Pemilihan sampel menggunakan metode Responden Driven Sampling (RDS) yakni sejenis metode chain-refferal sampling untuk populasi tersembunyi, yang dapat menghasilkan data yang representatif terkait populasi yang diteliti. ${ }^{8}$ Penasun dianggap sebagai populasi tersembunyi mengingat perilaku mereka yang berkaitan dengan Napza adalah ilegal, berbenturan dengan hukum. Langkah pertama metode RDS ini adalah menetapkan 7 seed awal yang memiliki karakteristik seheterogen mungkin, baik dari lokasi tempat tinggal, jenis hotspot, kelompok usia, pekerjaan/status sosial dan jenis kelamin, dengan metode ini diharapkan seluruh populasi Penasun di DKI Jakarta terwakili sebab karakter teman yang direkrut biasanya hampir sama dengan perekrutnya yang merupakan peer groupnya. Penunjukan seed awal berdasarkan rekomendasi dari informan yang ditunjuk, yakni anggota LSM yang menangani kelompok Penasun yang sebelumnya adalah Penasun juga. Dari 7 seed awal masing-masing akan merekrut maksimal 3 orang, selanjutnya responden yang terekrut diberikan kesempatan untuk mengajak temannya maksimal 3 orang juga, demikian seterusnya sehingga terkumpul 240 responden. ${ }^{9}$

Analisis univariat dilakukan untuk mengetahui karakteristik responden berdasarkan variabel yang diteliti (Tabel no 1), untuk seleksi variabel yang masuk dalam analisis multivariat dilakukan analisis bivariat menggunakan chi square untuk menilai hubungan antara variabel dependen yakni status HIV dengan 10 variabel independen yakni status sifilis, jenis kelamin, kelompok umur, pendidikan, sikap konsisten tidak berbagi jarum suntik, lama penggunaan Napza suntik, frekuensi menyuntik, jual seks/tukar bodi, hubungan seks setahun terakhir dan perilaku seks berisiko, kekuatan hubungan diukur dengan PR (Prevalens Rasio) (Tabel no 2), selanjutnya untuk melihat hubungan antar variabel dilakukan analisis Multivariat pada variabel yang memenuhi kriteria, yakni memiliki $p$ value $<0,25$ (Tabel no 3, 4, 5 dan 6). Analisis data menggunakan sofware STATA 12, variabel yang bermakna pada hasil studi ini dijadikan sebagai referensi untuk melakukan intervensi program. ${ }^{10}$

\section{Hasil}

Prevalensi HIV di kalangan Penasun DKI Jakarta adalah 49,2\% sedangkan prevalensi Sifilis hanya 3,8\%. Berdasarkan jenis kelamin, 9,6\% responden adalah wanita, sisanya 90,4\% pria. Usia termuda responden 17 tahun dan tertua 60 tahun, 85,8\% berada pada kelompok usia produktif yakni 21 - 40 tahun. Variabel 
Inggarawati, Ronoatmodjo Faktor Risiko yang berhubungan dengan infeksi HIV pada pengguna NAPZA (Penasun) DKI Jakarta Tahun 2013-2014 sikap sharing jarum suntik dinilai dari kuesioner SCP Penasun 2013 pertanyaan P301 a, b, c, d, e, f; dinyatakan tidak sharing jarum suntik bila jawaban P301 a-e dijawab tidak dan P301 f dijawab ya, hasil pengukuran variabel ini didapatkan hanya 23,3\% menyatakan tidak sharing, sisanya 76,7\% masih melakukan sharing jarum suntik.

Tabel 1. Karakteristik Responden berdasarkan variabel dependen dan independen

\begin{tabular}{|c|c|c|c|}
\hline & Karakteristik Responden & Jumlah & $\begin{array}{c}\text { Persentase } \\
\text { (\%) }\end{array}$ \\
\hline 1. & $\begin{array}{l}\text { Hasil Pemeriksaan HIV } \\
-\quad \text { Reaktif } \\
-\quad \text { Non Reaktif }\end{array}$ & $\begin{array}{l}118 \\
122 \\
\end{array}$ & $\begin{array}{l}49.2 \\
50.8 \\
\end{array}$ \\
\hline 2. & $\begin{array}{ll}\text { Hasil Pemeriksaan Sifilis } \\
-\quad \text { Reaktif } \\
-\quad \text { Non Reaktif }\end{array}$ & $\begin{array}{c}9 \\
231 \\
\end{array}$ & $\begin{array}{c}3.8 \\
96.2 \\
\end{array}$ \\
\hline 3. & $\begin{array}{l}\text { Jenis Kelamin } \\
-\quad \text { Perempuan } \\
-\quad \text { Laki-laki } \\
\end{array}$ & $\begin{array}{c}23 \\
217 \\
\end{array}$ & $\begin{array}{c}9.6 \\
90.4\end{array}$ \\
\hline 4. & $\begin{array}{l}\text { Umur } \\
-\quad 17-20 \text { tahun } \\
-\quad 21-30 \text { tahun } \\
-\quad 31-40 \text { tahun } \\
-\quad 41-50 \text { tahun } \\
-\quad 51-60 \text { tahun }\end{array}$ & $\begin{array}{c}12 \\
97 \\
109 \\
18 \\
4\end{array}$ & $\begin{array}{c}5 \\
40.4 \\
45.4 \\
7.5 \\
1.7\end{array}$ \\
\hline 5. & \begin{tabular}{ll}
\multicolumn{2}{l}{ Tingkat Pendidikan } \\
- $\quad$ Tidak Sekolah \\
- & SD \\
- & SMP \\
- & SMA \\
- & PT
\end{tabular} & $\begin{array}{c}4 \\
31 \\
63 \\
123 \\
19\end{array}$ & $\begin{array}{c}1.7 \\
12.9 \\
26.2 \\
51.3 \\
7.9\end{array}$ \\
\hline 6. & $\begin{array}{l}\text { Lama jadi Penasun } \\
\text { - } \quad 1 \text { sd } 12 \text { bulan } \\
\text { - } \quad 13 \text { sd } 60 \text { bulan } \\
\text { - } \quad 61 \text { sd } 120 \text { bulan } \\
\text { - } \quad 121 \text { sd } 240 \text { bulan } \\
\end{array}$ & $\begin{array}{l}18 \\
58 \\
73 \\
91\end{array}$ & $\begin{array}{c}7.5 \\
24.2 \\
30.4 \\
37.9 \\
\end{array}$ \\
\hline 7. & $\begin{array}{l}\text { Sikap Sharing Jarum Suntik } \\
-\quad \text { Sharing } \\
\text { - } \quad \text { Tidak Sharing }\end{array}$ & $\begin{array}{c}184 \\
56\end{array}$ & $\begin{array}{l}76.7 \\
23.3\end{array}$ \\
\hline 8. & $\begin{array}{ll}\text { Jual Sex } \\
-\quad \text { Ya } \\
-\quad \text { Tidak }\end{array}$ & $\begin{array}{c}4 \\
236\end{array}$ & $\begin{array}{c}1.7 \\
98.3\end{array}$ \\
\hline 9. & $\begin{array}{l}\text { Frekuensi menyuntik sebulan } \\
\text { terakhir } \\
\text { - } \quad \text { Tidak menyuntik } \\
\text { - } \quad \text { Menyuntik tdk tiap hari } \\
\text { - } \quad \text { Menyuntik tiap hari }\end{array}$ & $\begin{array}{r}26 \\
69 \\
145 \\
\end{array}$ & $\begin{array}{l}10.8 \\
28.8 \\
60.4 \\
\end{array}$ \\
\hline 10. & $\begin{array}{l}\text { Melakukan Hubungan Sex } \\
\text { setahun Terakhir } \\
\text { - Ya } \\
\text { - } \quad \text { Tidak }\end{array}$ & $\begin{array}{c}164 \\
76\end{array}$ & $\begin{array}{l}68.3 \\
31.7\end{array}$ \\
\hline 11. & $\begin{array}{l}\text { Melakukan Hubungan Sex } \\
\text { Berisiko } \\
\text { - Ya } \\
\text { - } \quad \text { Tidak }\end{array}$ & $\begin{array}{c}209 \\
31\end{array}$ & $\begin{array}{l}87.1 \\
12.9 \\
\end{array}$ \\
\hline
\end{tabular}

Dilakukan analisis bivariat variabel dependen status HIV dengan 10 variabel independent didapatkan hasil seperti pada tabel 2. Berdasarkan status Sifilis didapatkan 78\% penasun dengan hasil tes sifilis positif memiliki status HIV positif juga dan hanya $8,4 \%$ status

sifilis negatif yang hasil tes HIV nya positif, PR sebesar 1,62 (95\% CI $=1.1-2.4)$ secara statistik bermakna, artinya Penasun dengan Sifilis positif berisiko 1,62 kali untuk terinfeksi HIV dibanding Penasun dengan Sifilis negatif. Ditinjau dari jenis kelamin, Penasun perempuan lebih berisiko untuk terkena HIV 1,27 kali untuk terinfeksi HIV dibanding penasun laki-laki namun walaupun secara statistik tidak bermakna $(95 \%$ CI = 0.9 - 1.8) hal ini dimungkinkan karena keterbatasan jumlah sampel. Variabel umur dikelompokkan menjadi dua yakni e"29 tahun dan <29 tahun, pembagian berdasarkan analisis ROC. ${ }^{11}$

Berdasarkan kelompok umur, 56,8\% status HIV positif berada pada kel umur 29 - 60 tahun dan 33,3\% pada kel umur 17 - 28 tahun, nilai PR 1,7 (95\% CI = 1,2 - 2.4) bermakna secara statistik. Berdasarkan Pendidikan tidak ada perbedaan risiko HIV berdasarkan Pendidikan. Berdasarkan variabel perilaku sharing jarum suntik, didapatkan bahwa 57,6\% HIV positif melakukan sharing jarum suntik hanya $21,4 \%$ tidak sharing, nilai PR 2,69 (95\% CI =1.6 - 4.5) secara statistik bermakna, artinya sikap sharing jarum suntik berisiko terhadap infeksi HIV sebesar 2,69 kali dibanding penasun yang memiliki sikap konsisten untuk tidak sharing jarum suntik. Variabel lama jadi penasun dikelompokkan menjadi 2 dengan penetapan cut off point berdasarkan perhitungan Youden's indeks.

Berdasarkan variabel lama menjadi penasun, sebanyak $68,3 \%$ penasun dengan status HIV positif telah menggunakan napza suntik antara 120 - 240 bulan dan 35,3\% menggunakan napza suntik antara 1 sd 119 bulan, lama pemakaian jarum suntik e" 120 bulan berisiko terinfeksi HIV sebesar 1,94 kali dibanding pemakaian jarum suntik <120 bulan (95\% $\mathrm{CI}=1.5-2.5$ ), hubungan tersebut bermakna secara statistik. Pada variabel jual seks, 50\% yang mengaku menjual seks memiliki status HIV positif dan 49,2\% yang mengaku tidak menjual seks hasil tes HIV nya positif juga, tidak terdapat hubungan antara jual seks dengan status HIV PR 1,02 (95\% CI = $0.4-2.7)$.

Variabel frekuensi menyuntik sebulan terakhir dikelompokkan menjadi 2 berdasarkan kuesioner SCP 2013 (P205) yakni tidak menyuntik sebulan terakhir dan menyuntik sebulan terakhir, 49,5\% penasun HIV positif menyuntik dalam sebulan terakhir dan 46,2\% mengaku tidak menyuntik dalam sebulan terakhir, PR $1,07$ (95\% CI $=0.7-1.7)$ artinya tidak terdapat hubungan antara frekuensi menyuntik sebulan terakhir dengan infeksi HIV. Variabel hubungan seks setahun terakhir, sebanyak 48,2\% penasun dengan HIV positif melakukan hubungan seks setahun terakhir dan 51,3\% mengaku tidak melakukan hubungan seks dalam setahun terakhir, PR 0,94 (95\% CI= 0.7 - 1.2) artinya tidak terdapat hubungan antara hubungan seks setahun terakhir dengan infeksi HIV pada Penasun. 
Tabel 2. Analisis Bivariat Status HIV dengan Variabel Independen

\begin{tabular}{|c|c|c|c|c|c|c|c|c|c|}
\hline & & Karakteristik & & & IV & & & & \\
\hline & Variabel & & $\mathrm{N}$ & $\%$ & $\mathrm{~N}$ & $\%$ & PR & $95 \%$ CI & pV \\
\hline & & Reaktif & 7 & 78.0 & 2 & 22.0 & 1.62 & $1.1-2.4$ & 0.08 \\
\hline 1. & Status Sifilis & Non Reaktif & 11 & 8.4 & 120 & 91.6 & & & \\
\hline 2. & Jenis Kelamin & Perempuan & 14 & 61.0 & 9 & 39.0 & 1.27 & $0.9-1.8$ & 0.24 \\
\hline & & Laki-laki & 104 & 48.0 & 113 & 52.0 & & & \\
\hline 3 & Umur & 29-60 tahun & 92 & 56.8 & 70 & 43.2 & 1.70 & $1.2-2.4$ & 0.00 \\
\hline & Umur & 17-28 tahun & 26 & 33.2 & 52 & 66.8 & & & \\
\hline 4. & Tingkat & $\begin{array}{l}\text { Tidak Sekolah - } \\
\text { SMP }\end{array}$ & 46 & 46.9 & 52 & 53.1 & 0.93 & $0.7-1.2$ & 0.57 \\
\hline & Pendidikan & SMA - PT & 72 & 50.7 & 70 & 49.3 & & & \\
\hline & & Sharing & 106 & 57.6 & 78 & 42.4 & 2.69 & $1.6-4.5$ & 0.00 \\
\hline 5. & $\begin{array}{l}\text { Perilaku sharing } \\
\text { jarum suntik }\end{array}$ & Tidak Sharing & 12 & 21.4 & 44 & 78.6 & & & \\
\hline 6. & Lama jadi & 120-240 bulan & 69 & 68.3 & 32 & 31.7 & 1.94 & $1.5-2.5$ & 0.00 \\
\hline & Penasun & 1-119 bulan & 49 & 35.3 & 90 & 64.7 & & & \\
\hline 7 & the S S & Ya & 2 & 50.0 & 2 & 50.0 & 1.02 & $0.4-2.7$ & 0.97 \\
\hline 1. & Jual sex & Tidak & 116 & 49.2 & 120 & 50.8 & & & \\
\hline 8. & Frekuensi & $\begin{array}{l}\text { Menyuntik dalam } \\
\text { sebulan }\end{array}$ & 106 & 49.5 & 108 & 50.5 & 1.07 & $0.7-1.7$ & 0.74 \\
\hline & $\begin{array}{l}\text { menyuntik } \\
\text { sebulan terakhir }\end{array}$ & $\begin{array}{l}\text { Tidak menyuntik } \\
\text { dalam } 1 \text { bulan }\end{array}$ & 12 & 46.2 & 14 & 53.8 & & & \\
\hline 9. & Hubungan Sex & Ya & 79 & 48.2 & 85 & 51.8 & 0.94 & $0.7-1.2$ & 0.65 \\
\hline & setahun Terakhir & Tidak & 39 & 51.3 & 37 & 48.7 & & & \\
\hline 10. & Perilaku Sex & Ya & 104 & 49.8 & 105 & 50.2 & 1.1 & $0.73-1.67$ & 0.62 \\
\hline & Berisiko & Tidak & 14 & 45.2 & 17 & 54.8 & & & \\
\hline
\end{tabular}

Berdasarkan variabel perilaku seks berisiko yang diambil dari kuesioner SCP 2013 (P402) didapatkan $49,8 \%$ penasun HIV positif melakukan perilaku seks berisiko dan 45,2\% tidak melakukan seks berisiko, PR 1,1 (95\% CI = $0.73-1.67)$, artinya tidak terdapat hubungan antara perilaku seks berisiko dengan infeksi HIV pada Penasun. Dilakukan analisis multivariat menggunakan cox regression pada variabel dengan nilai $P<0,25$ yakni perilaku sharing jarum suntik, lama jadi penasun, kelompok umur, status sifilis dan jenis kelamin, variabel waktu dibuat konstan (time $=1)^{12}$

Berikut adalah tabel hasil analisis multivariat:

Tabel 3. Model Awal Analisis Multivariat Cox Regression

\begin{tabular}{lcccc}
\hline Variabel & $\mathrm{z}$ & Nilai P & $\mathrm{PR}$ & $95 \% \mathrm{CI}$ \\
\hline Perilaku sharing jarum suntik & 2.94 & 0.003 & 2.46 & $1.35-4.49$ \\
Sifilis & 0.95 & 0.340 & 1.51 & $0.65-3.65$ \\
Jenis Kelamin & 0.61 & 0.541 & 1.21 & $0.65-2.27$ \\
Kel Umur & 1.63 & 0.103 & 1.46 & $0.93-2.30$ \\
Lama menjadi Penasun & 2.46 & 0.014 & 1.62 & $1.10-2.38$ \\
\hline
\end{tabular}

Tujuan dari analisis multivariat ini adalah mendapatkan model terbaik untuk memprediksi kejadian HIV dikalangan Penasun dengan mempertimbangkan seluruh variabel yang diduga berhubungan dengan kejadian HIV, model awal didapatkan dari 5 variabel independen memiliki peran dalam kejadian HIV dengan kemaknaan yang berbeda, variabel perilaku sharing jarum suntik adalah faktor terbesar pada kejadian HIV dikalangan Penasun setelah dikontrol variabel lainnya. Untuk mendapatkan model terbaik, satu persatu variabel yang memiliki nilai $P$ tertinggi dikeluarkan dari model (metode backward).

Pada saat variabel jenis kelamin dikeluarkan terlihat perbedaan PR dari variabel perilaku sharing jarum suntik sebesar 0,02 atau $<10 \%$, artinya variabel jenis kelamin bukan merupakan variabel perancu dan dapat dikeluarkan, setelah variabel jenis kelamin dikeluarkan terlihat variabel sifilis memiliki nilai $P$ tertinggi, maka dikeluarkan dari model, didapatkan perbedaan nilai PR variabel perilaku sharing jarum suntik sebesar 0,01 atau $<10 \%$ dari full model, sehingga bukan merupakan variabel perancu dan dapat dikeluarkan dari model. Selanjutnya terdapat 3 variabel yang memprediksi kejadian HIV pada Penasun, variabel kelompok umur memiliki nilai $P$ tertinggi sehingga dikeluarkan dari model, perbedaan nilai PR variabel perilaku jarum suntik setelah variabel kelompok umur dikeluarkan adalah sebesar 0,03 atau $<10 \%$, sehingga variabel kelompok umur bukan merupakan variabel perancu sehingga dapat dikeluarkan dari model, disamping itu umur juga merupakan variabel yang tidak dapat diintervensi. Didapatkan model akhir pada studi ini variabel independent yang paling berkontribusi terhadap kejadian HIV pada Penasun adalah perilaku sharing jarum suntik dan lama menjadi penasun. Perilaku sharing jarum suntik dapat meningkatkan risiko terkena HIV sebesar 2,42 kali setelah dikontrol oleh variabel lama menjadi Penasun.

Untuk menilai apakah terdapat hubungan antar variabel independen yakni perilaku sharing jarum suntik dengan lama menjadi penasun dilakukan analisis chi square, didapatkan hasil sebagai berikut: 
Tabel 4. Model Analisis Multivariat Cox Regression

(dikeluarkan variable JK, Sifilis, kel umur satu persatu)

\begin{tabular}{lcccc}
\hline Variabel & z & Nilai P & PR & 95\% व \\
\hline Perilaku sharing jarum suntik & 2.94 & 0.003 & 2.46 & $1.35-4.49$ \\
Sifilis & 0.95 & 0.340 & 1.51 & $0.65-3.65$ \\
Kel Umur & 1.63 & 0.103 & 1.46 & $0.93-2.30$ \\
Lama menjadi Penasun & 2.46 & 0.014 & 1.62 & $1.10-2.38$ \\
\hline Dikeluarkan variabel sifilis & & & & \\
\hline Perilaku sharing jarum suntik & 2.92 & 0.004 & 2.45 & $1.34-4.46$ \\
Kel Umur & 1.55 & 0.120 & 1.43 & $0.91-2.26$ \\
Lama menjadi Penasun & 2.43 & 0.015 & 1.61 & $1.10-2.37$ \\
\hline Model akhir cox regression & & & & \\
\hline Perilaku sharing jarum suntik & 2.88 & 0.004 & 2.42 & $1.33-4.41$ \\
Lama menjadi Penasun & 3.05 & 0.015 & 1.78 & $1.23-2.57$ \\
\hline
\end{tabular}

Pada saat variabel jenis kelamin dikeluarkan terlihat perbedaan PR dari variabel perilaku sharing jarum suntik sebesar 0,02 atau $<10 \%$, artinya variabel jenis kelamin bukan merupakan variabel perancu dan dapat dikeluarkan, setelah variabel jenis kelamin dikeluarkan terlihat variabel sifilis memiliki nilai $P$ tertinggi, maka dikeluarkan dari model, didapatkan perbedaan nilai PR variabel perilaku sharing jarum suntik sebesar 0,01 atau $<10 \%$ dari full model, sehingga bukan merupakan variabel perancu dan dapat dikeluarkan dari model. Selanjutnya terdapat 3 variabel yang memprediksi kejadian HIV pada Penasun, variabel kelompok umur memiliki nilai $P$ tertinggi sehingga dikeluarkan dari model, perbedaan nilai PR variabel perilaku jarum suntik setelah variabel kelompok umur dikeluarkan adalah sebesar 0,03 atau $<10 \%$, sehingga variabel kelompok umur bukan merupakan variabel perancu sehingga dapat dikeluarkan dari model, disamping itu umur juga merupakan variabel yang tidak dapat diintervensi. Didapatkan model akhir pada studi ini variabel independent yang paling berkontribusi terhadap kejadian HIV pada Penasun adalah perilaku sharing jarum suntik dan lama menjadi penasun. Perilaku sharing jarum suntik dapat meningkatkan risiko terkena HIV sebesar 2,42 kali setelah dikontrol oleh variabel lama menjadi Penasun.

Untuk menilai apakah terdapat hubungan antar variabel independen yakni perilaku sharing jarum suntik dengan lama menjadi penasun dilakukan analisis chi square, didapatkan hasil sebagai berikut:

Tabel 5. Model Analisis Bivariat pada Variabel Perilaku Sharing Jarum Suntik

\begin{tabular}{|c|c|c|c|c|}
\hline \multirow[t]{2}{*}{ Variabel } & \multicolumn{2}{|c|}{$\begin{array}{c}\text { Perilaku sharing jarum } \\
\text { suntik }\end{array}$} & \multirow[t]{2}{*}{ PR } & \multirow[t]{2}{*}{$95 \% \propto$} \\
\hline & Sharing & Tidak sharing & & \\
\hline $\begin{array}{l}\text { Lama meniadi } \\
\text { penasun }\end{array}$ & & & & \\
\hline - 120-240 bulan & 106 & 12 & & \\
\hline -1-119 bulan & 78 & 44 & 1.18 & $1.03-1.35$ \\
\hline
\end{tabular}

Lama menjadi Penasun mempengaruhi sikap Perilaku sharing Jarum suntik, Penasun yang telah menyuntik selama 120 - 240 bulan berisiko untuk berperilaku sharing jarum suntik sebesar 1.18 kali dibanding Penasun yang menyuntik kurang dari 120 bulan.

\section{Diskusi}

Dari 10 variabel yang diteliti sebagai determinan infeksi HIV pada penasun didapatkan 5 variabel yang memenuhi kriteria untuk dilakukan analisis multivariat cox regression, model akhir analisis multivariat didapatkan 2 variabel menjadi faktor utama infeksi HIV pada kelompok penasun yakni variabel Perilaku Sharing Jarum Suntik dan lama pemakaian napza suntik, keduanya merupakan faktor yang meningkatkan risiko infeksi HIV pada kelompok penasun, dengan Prevalens Rasio (PR) masing-masing sebesar 2,42 $(95 \%=1.33-4.41)$ dan 1,78(95\% CI= 1.23 - 2.57), sejalan dengan penelitian Sri Herwanti S, 2017 sharing jarum suntik memiliki risiko 1,90 kali terinfeksi HIV (95\% CI= 0,68 - 5,35). ${ }^{13}$ Faktor risiko utama kejadian HIV pada penasun adalah pemakaian jarum suntik secara bergantian, pada umumnya satu jarum suntik dipakai oleh 2 sampai 15 orang pengguna narkotika, ${ }^{9}$ berdasarkan hal ini WHO merekomendasikan program jarum dan alat suntik steril serta terapi subtitusi opioid sebagai strategi pengendalikan HIV dikalangan penasun di Afrika sebagai program pengurangan dampak buruk (harm reduction). Program ini dilaksanakan di 63\% Negara dikawasan Afrika yang memiliki populasi penasun. ${ }^{14}$ Studi ini mendapatkan bahwa mayoritas penasun $(76,7 \%)$ melakukan sharing jarum suntik dan hanya sebagian kecil $(23,3 \%)$ yang memiliki sikap konsisten tidak sharing jarum suntik, ternyata sikap ini sangat menentukan apakah seorang penasun nantinya akan tertular HIV atau tidak. Agar terlindung dari HIV penasun tidak boleh sekalipun menggunakan alat suntik bekas atau selalu menggunakan alat suntik baru. Tingginya prevalensi HIV di kalangan Penasun tentunya meningkatkan risiko jarum bekas pakai telah digunakan oleh penderita HIV sebelumnya, bahkan bukan hanya oleh satu orang penderita HIV karena pemakaian bersama rata-rata oleh 2 - 15 orang, dengan kondisi tersebut, walaupun hanya sekali menggunakan jarum bekas pakai dapat dipastikan jarum tersebut telah terinfeksi HIV meskipun belum dapat dipastikan apakah langsung berkembang menjadi HIV atau tidak.

Lama jadi penasun adalah variabel kedua yang behubungan dengan infeksi HIV dikalangan Penasun, hasil analisis mendapatkan semakin lama menjadi Penasun risiko untuk terinfeksi HIV semakin besar, hal ini dimungkinkan karena sikap Penasun yang semula tidak mau berbagi jarum suntik seiring pertambahan waktu sikap tersebut menjadi lemah karena godaan 

teman (peer group), perilaku yang tidak terkontrol pada saat withdrawal (sakau) dan kemungkinan kesulitan mendapatkan jarum suntik steril juga turut melemahkan sikap yang tadinya tidak mau berbagi jarum suntik, dalam penelitian ini didapatkan juga bahwa lama menjadi penasun berhubungan secara bermakna dengan perilaku sharing jarum suntik, PR 1,2 (95\% CI $=1,03-1,35)$. Variabel umur adalah variabel ketiga yang berhubungan dengan infeksi HIV di kalangan Penasun, hasil analisis multivariat menunjukkan bahwa kelompok umur merupakan faktor risiko terhadap infeksi HIV di kalangan Penasun dengan nilai PR 1,43 (95\% CI = 0,91 - 2,26), artinya Penasun usia tua lebih berisiko terkena HIV dibanding yang berusia muda walaupun secara statistik tidak bermakna, hasil analisis mendapatkan pula bahwa tidak terdapat hubungan antara kelompok umur dengan perilaku sharing jarum suntik. Metode pemeriksaan HIV yang digunakan dalam sero survei HIV ini adalah metode tidak langsung, yakni dengan mendeteksi respon imun terhadap infeksi HIV atau konsekuensi klinis dari infeksi HIV, metode ini memiliki kerugian terutama karena respon imun memerlukan jangka waktu tertentu sejak infeksi HIV hingga timbul reaksi tubuh, periode ini disebut window period, pada periode ini walaupun seseorang telah terinfeksi HIV namun masih memberikan hasil negatif pada pemeriksaan antibodinya, window period ini biasanya berlangsung selama 3 s.d. 6 bulan, namun sebagian besar kurang dari 3 bulan, ${ }^{15}$ sehingga disarankan untuk mengulang pemeriksaan setiap 3 bulan bagi kelompok berisiko, hal ini juga dapat mempengaruhi prevalensi HIV yang lebih tinggi pada kelompok usia yang lebih tinggi.

Prevalensi Sifilis di kalangan Penasun sangat kecil yakni 3,8\% jauh lebih kecil dibanding prevalensi Sifilis di kalangan LSL yakni 14,2\% dan Waria sebesar 29\% namun Sifilis berperan dalam kejadian HIV pada Penasun sebesar 1,70 (95\% CI= 0,79 - 3,65), artinya Penasun dengan Sifilis positif berisiko 1,7 kali untuk terinfeksi HIV dibanding Penasun yang tidak menderita Sifilis, hubungan ini tidak bermakna secara statistik, hal ini dimungkinkan karena jumlah sampel yang kurang, tujuan utama dari kegiatan survei ini adalah mencari prevalensi HIV dan Sifilis di kalangan Penasun. Suatu studi yang dilakukan di Denmark terhadap lebih dari 2000 pasien yang didiagnosis HIV dalam PAPDI 2011,16 mendapatkan bahwa Infeksi Menular Seksual dan Virus Hepatitis berhubungan dengan infeksi HIV dengan OR 12,3 (95\% CI $=9,6-15,7)$, sejalan dengan penelitian Sri Hermawanti S, 2017 yakni riwayat IMS atau status sifilis positif berisiko terhadap HIV positif sebesar 1,23 kali $(95 \% \mathrm{CI}=0,44-3,43)$. Penelitian Amalia dkk di Jawa Tengah terkait perilaku seks Penasun mendapatkan bahwa 37,2\% responden melakukan seks tidak aman yakni tidak menggunakan kondom saat melakukan seks berisiko. ${ }^{17}$

Dalam penelitian ini juga mendapatkan bahwa Penasun wanita berisiko untuk terinfeksi HIV 1,21 kali dibanding Penasun pria (95\% CI=0.65 - 2.27) walaupun secara statistik tidak bermakna, hal ini dapat disebabkan oleh jumlah Penasun wanita yang menjadi responden penelitian sangat sedikit dibanding Penasun pria (prevalensi 9,6\%), wanita lebih berisiko untuk terinfeksi HIV dibanding pria di kalangan Penasun dimungkinkan karena wanita umumnya dalam posisi yang lemah, kemampuan untuk menjaga dirinya dengan cara menggunakan jarum suntik steril lebih rendah dibanding laki-laki, akses ke layanan jarum suntik steril pun lebih terbatas, terlebih stigma dari keluarga dan masyarakat yang dapat membuatnya merasa putus asa, disamping itu pada umumnya Penasun wanita melakukan tukar bodi/menjual seks untuk mendapatkan Narkoba, hal ini meningkatkan risiko infeksi HIV di kalangan Penasun wanita. Variabel yang secara teori berhubungan dengan kejadian HIV namun pada penelitian ini tidak terbukti adalah jual seks dan perilaku seks berisiko hal ini terjadi karena kemungkinan bias informasi, dalam kuesioner pertanyaan untuk perilaku seks hanya untuk 1 tahun terakhir, konsistensi jawaban responden pun perlu penilaian lebih lanjut. Pada survei ini 87,1\% penasun mengaku melakukan seks berisiko, yakni dengan pasangan tidak tetap dan tanpa kondom, sejalan dengan penelitian yang dilakukan I. Praptoharardjo dkk pada tahun 2007 yang mendapatkan bahwa 60\% penasun pria sering mengunjungi pekerja seks, 72\% diantaranya tidak menggunakan kondom, sementara 63\% Penasun wanita menjadi pekerja seks dalam studi tersebut. Penyebaran HIV dari penasun kepada kalangan masyarakat umum juga terjadi melalui mekanisme seks tidak aman ini, sebagaimana penelitian Besral dkk pada tahun 2004.

Model akhir analisis multivariat cox regression mendapatkan bahwa variabel perilaku sharing jarum suntik meningkatkan risiko infeksi HIV di kalangan Penasun setelah dikontrol oleh variabel lama menjadi penasun. Variabel lama menjadi penasun merupakan variabel perancu, sebab disamping berhubungan dengan variabel dependen yakni HIV juga mempengaruhi variabel perilaku sharing jarum suntik. Semakin lama menjadi Penasun, semakin meningkatkan risiko sharing jarum suntik, sehingga kemungkinan tertular HIV pun semakin besar.

\section{Kesimpulan dan Saran}

Perilaku sharing jarum suntik dan lama menjadi Penasun adalah variabel yang sangat berperan pada infeksi HIV di kalangan Penasun. Kedua variabel ini dapat dilakukan modifikasi, variabel berikutnya yang juga berhubungan dengan infeksi HIV di kalangan Penasun walaupun tidak bermakna secara s tatistik 
Inggarawati, Ronoatmodjo Faktor Risiko yang berhubungan dengan infeksi HIV pada pengguna NAPZA (Penasun) DKI Jakarta Tahun $2013-2014$

adalah kelompok umur, sifilis dan jenis kelamin. Variabel yang pengaruhnya paling besar terhadap infeksi HIV di kalangan Penasun adalah sikap sharing jarum suntik, sikap konsisten tidak sharing jarum suntik dalam berbagai keadaan mampu melindungi Penasun dari HIV, sebaliknya perilaku sharing jarum suntik walaupun hanya sesekali meningkatkan risiko infeksi HIV. Lama menjadi penasun disamping faktor risiko infeksi HIV mempengaruhi juga perilaku sharing jarum suntik di kalangan Penasun.

Pengendalian HIV dikalangan Penasun melalui program yang telah ada di Jakarta saat ini antara lain Program Layanan Alat Suntik Steril (LASS) dan Program Terapi Rumatan Metadhone (PTRM) perlu dipertahankan dan ditingkatkan, harapannya seluruh Penasun mampu menjangkau program ini. Program lain yang tidak kalah penting untuk dilakukan adalah promosi kesehatan di kalangan Penasun, terutama yang masih berusia muda, tujuannya adalah membangun sikap konsisten untuk tidak sharing jarum suntik dan mendorong Penasun untuk segera beralih dari suntik ke oral secara perlahan dan bertahap. Program penggunaan kondom di kalangan Penasun baik Penasun laki-laki maupun wanita juga perlu dilakukan karena terdapat hubungan antara infeksi menular seksual (sifilis) dengan infeksi HIV dikalangan Penasun.

\section{Referensi}

1. Kemenkes RI. Kajian Epidemiologi HIV Indonesia 2016. 2017;1-66

2. Kemenkes RI. Estimasi dan Proyeksi HIV/AIDS di indonesia Tahun 2011 - 2016. 2014. p. 10

3. Ingggariwati. Hubungan antara perilaku seks dengan infeksi HIV pada populasi lelaki suka seks lelaki di DKI Jakarta tahun 2013. PAEI. 2018;1.

4. L Degenhardt. Peacock. Colledge. Global prevalence of injecting drug use and sociodemographic characteristics and prevalence of HIV, HBV and HCV in people who inject drugs: a multistage systematic review. Lancet Glob Heal. 2017;

5. Wiessing BMLDBPL. Global Epidemiology of injecting drug use and HIV among people who inject drugs: a sistematic review. Lancet. 2008;10:372.

6. Komisi Penanggulangan AIDS. Protokol Lapangan Survei Cepat Perilaku Penasun. 2013. Jakarta.

7. Kemenkes RI. Protokol Lapangan Biologis Sentinel Surveilans HIV (Integrasi dengan Survei Cepat Perilaku). 2013.

8. Praptoraharjo I, Wiebel WW, Kamil O, Iii AP. JARINGAN SEKSUAL DAN PERILAKU BERISIKO PENGGUNA NAPZA SUNTIK/ : EPISODE LAIN PENYEBARAN HIV DI INDONESIA. 2007;23(3):106-18.

9. Fink HH, Nevendorff L, Gabriella A, Verina L. Studi Kasus/ : Integrasi Respon HIV dan AIDS ke dalam Sistem Kesehatan dan Efektivitas Program Layanan Alat Suntik Steril di DKI Jakarta. PPH Atmajaya. 2015;

10.Sopiyudin Dahlan. 13 Penyakit Statistik disertai Aplikasi Program Stata. Jakarta; 2010. 15 p.

11. Youden J. Youden's J Statistic [Internet]. wikipedia.org. 2017. Available from: https://en.wikipedia.org/wiki William_J_Youden
12.Kleinbaum. David G. Survival Analisys a Self Learning Text third edition. Business Media, LLC; 2012.

13.Saputra S Herwanti (Epidemiologi FKM UI). Determinan yang Mempengaruhi Terjadinya Infeksi HIV pada Pengguna Napza Suntik di Indonesia tahun 2015 (Analisis Data STBP tahun 2015). UI; 2018.

14. WHO. Focus On Key Populations In National HIV Strategic Plans in The African Region. 2018; (September).

15. J.Nelwan Erni. Rudi W R. Gejala dan Diagnosis HIV. In: PAPDI IPD Edisi VI. Jakarta; 2014. p. 910.

16.Djoerban Zubairi. S Djauzi R. HIV/AIDS di Indonesia. In: PAPDI IPD Edisi VI. Jakarta; 2014. p. 887.

17.Cahyani Amalia Eka, Widjanarko Bagoes LB. Gambaran Perilaku Berisiko HIV pada Pengguna Napza Suntik di Provinsi Jawa Tengah. Promosi Kesehat Indones. 2015;10. 
Jurnal Epidemiologi Kesehatan Indonesia Vol. 2, No. 2, Desember 2018 